\title{
SOCIAL AND INSTITUTIONAL PRESENCE OF THE HEADS OF GOVERNMENT OF THE AMERICAS ON SOCIAL MEDIA
}

an analysis of the communication on Twitter about COVID-19

Lucas Dejard Moreira Mendonça ${ }^{1}$

Universidade Federal do Pará (UFPA) erlucomlpg@gmail.com

Harold Dias de Mello Junior ${ }^{3}$

Universidade do Estado do Rio de Janeiro (UERJ) harold.dias@gmail.com

Karla Figueiredo 5 PUC Rio karlafigueiredo@ime.uerj.br

Marcos César da Rocha Seruffo ${ }^{7}$ Universidade Federal do Pará (UFPA) marcos.seruffo@gmail.com
Adriano Madureira dos Santos ${ }^{2}$

Universidade Federal do Pará (UFPA) adrianomadureira1@gmail.com

Rita de Cássia Romeiro Paulino ${ }^{4}$ Universidade Federal de Santa Catarina (UFSC) rcpauli@gmail.com

Fernando Augusto Ribeiro Costa ${ }^{6}$ Universidade Federal do Pará (UFPA) fernando.costa@naea.ufpa.br

\begin{abstract}
This article examined the personal profiles of the Heads of Government of countries in South/North America and how they communicated with their audiences on institutional measures to contain COVID-19. Analyses were carried out on data collected from Twitter from November-2019 to November-2020. This study includes: i) quantitative analysis, measuring categories and emphases in the communication of tweets, retweets, likes, and comments on matters relevant to the pandemic; ii) qualitative analysis that allowed evaluating speeches to identify political interference and the effectiveness of communication at critical moments of the pandemic. It was possible to infer that each president has his singularities and understanding about Social Media's use as a more direct communication tool with his audience. It was also found that successful communication is not directly proportional to the volume of messages on Twitter, but to socio-political aspects and institutional leadership that can make a difference in Social Media in combating COVID-19.
\end{abstract}

Keywords: Social Presence. Populism. Presidents of America. Twitter. Social Network Analysis. COVID-19.

\section{PRESENÇA SOCIAL E INSTITUCIONAL DOS CHEFES DE GOVERNO DAS AMÉRICAS NAS REDES SOCIAIS}

uma análise da comunicação no Twitter sobre o COVID-19

\section{Resumo}

Este artigo examinou os perfis pessoais dos Chefes de Governo dos países da América do Sul / do Norte e como eles se comunicaram com seus públicos sobre as medidas institucionais para conter o COVID-19. As análises foram realizadas em dados coletados do Twitter de novembro de 2019 a novembro de 2020 . Este estudo inclui: i) análise quantitativa, medição de categorias e ênfases na comunicação de tweets, retuítes, curtidas e comentários sobre assuntos relevantes para a pandemia; ii) análise qualitativa que permitiu avaliar discursos para identificar a interferência política e a eficácia da comunicação em momentos críticos da pandemia. Foi possível inferir que cada

${ }^{1}$ Estudante da Universidade Federal do Pará no curso de Engenharia da Computação.

${ }^{2}$ Graduando em Engenharia da Computação pela Universidade Federal do Pará.

${ }^{3}$ Doutorado em Engenharia Elétrica pela PUC do Rio de Janeiro. Professor Adjunto da Universidade do Estado do Rio de Janeiro.

${ }^{4}$ Doutorado em Engenharia e Gestão do Conhecimento pela Universidade Federal de Santa Catarina. Vice-Coordenadora da Pós-Graduação - PPGJOR do Programa de Pós-Graduação em Jornalismo.

${ }^{5}$ Mestrado e doutorado em Ciência da Computação pela Pontifícia Universidade Católica do Rio de Janeiro (PUC-Rio), o Dr. Figueiredo é o Chefe do Laboratório de Robótica e Inteligência Computacional (LIRA).

${ }^{6}$ Mestrando do Programa de Pós-Graduação em Desenvolvimento Sustentável do Trópico Úmido do Centro de Estudos do Alto Amazonas (PDTU / NAEA / UFPA).

${ }^{7}$ Doutor em Engenharia Elétrica com ênfase em Computação Aplicada. Professor na UFPA; no Programa de Pós-Graduação em Estudos Antrópicos da Amazônia (PPGEAA); no Programa de Pós-Graduação em Engenharia Elétrica (PPGEE) e no Programa de Pós-Graduação em Ciência da Computação (PPGCC). 
presidente tem suas singularidades e compreensão sobre o uso das Redes Sociais como ferramenta de comunicação mais direta com seu público. Verificou-se também que o sucesso da comunicação não é diretamente proporcional ao volume de mensagens no Twitter, mas aos aspectos sociopolíticos e lideranças institucionais que podem fazer a diferença nas Redes Sociais no combate ao COVID-19.

Keywords: Presença social. Populismo. Presidentes da América. Twitter. Análise de Redes Sociais. Covid-19.

\section{INTRODUCTION}

Innovations in Information Technologies, including social media platforms and smartphones, have boosted the generation of content with instant distribution and mass sharing through social media. This social behavior has been followed and recorded in reports and academic research that identify influencers, communities, the distribution and sharing of information, misinformation, bots $^{8}$, the types of speeches, as well as the insights that technology allows to obtain. At the tail of this movement, a sector of society, in particular, deals with this challenge: the governmental sphere and public institutions try to adapt or identify ways to establish an effective dialogue with the public.

The impact of social media in the public sector, as noted by Karakiza (2015), contributes decisively to the transformation of public administration towards a new and open format. Considering the pandemic scenario, the authors in Yum (2020) explore how public key players play an essential role in Twitter for COVID-19; When the study was applied, President Trump figures among the top 20 key players for both in-degree centrality and content in tweets. The main results show that governments should understand public key players' characteristics to promote information for COVID-19 in a timely manner.

A survey of Twitter data during the COVID-19 pandemic found that billions of people, with restrictions on full social interaction, used social media more. Specifically, Twitter's thirdquarter 2020 report indicates an annual increase of $29 \%$ of monetized active users, the largest increase ever recorded annually Twitter (2020).

According to Mossberger, $\mathrm{Wu}$, and Crawford (2013), the rapid adoption of social media, in particular, has the potential to provide convenient spaces for dialogue between citizens and the government. In a survey conducted by the USA Federal Government, Mergel (2013) identified that social media apps had become a source of recognized information and official government communication channels over the past three or four years.

\footnotetext{
${ }^{8}$ Diminutive of robot, it is a software application designed to simulate human actions in an automated way.
} 
Given this scenario and the changing paradigms of communication with social media, our research examines how was the social presence on Twitter, in times of the COVID-19 pandemic, of the Presidents of the USA, Brazil, Argentina, Mexico, Venezuela, Colombia, Bolivia, Ecuador, Uruguay, Chile, Paraguay and Peru and the Prime Minister of Canada. These countries' choice was motivated by the fact that they have accounts of presidents with a lot of activity on Twitter. The different attitudes of the Heads of Government of the USA, Brazil, Argentina, and Canada stand out.

Donald John Trump, former president of the United States for the Republican party, held political positions described as populist, protectionist, isolationist, and nationalist. According to McCormick (2016), Donald Trump claims that Facebook and Twitter helped him win the 2016 presidential election. The same social media company that helped him win also kicked him out of Twitter in 2021: 'We have permanently suspended the account due to the risk of further incitement to violence' Twitter (2020). At the time of data collection for this survey, Donald Trump's Twitter profile had more than 88 million followers. Rieger (2020) points out that he minimized the COVID-19 pandemic from the beginning, although the USA leads the ranking of countries with the highest number of deaths from the disease, as Joe Murphy and Muccari (2021).

Jair Messias Bolsonaro is a retired military man, politician and current president of Brazil. He was elected to the presidency by the Social Liberal Party (PSL) with promises of liberal reforms in the economy and with a conservative speech. At the moment, he is not affiliated with any party. He uses Twitter as a communication channel for his government and has more than six and a half million followers. Since the beginning of the pandemic, he has minimized the severity of COVID-19, describing it as a 'little flu', Guardian (2020).

Alberto Ángel Fernández, professor and lawyer, is the current president of Argentina. Belonging to the Justicialista Party, he was a candidate for the 'Frente de Todos', a coalition that brought together progressive oriented parties in the country, he is a representative of Kirchnerism ${ }^{9}$. Considered a center politician more than progressive, he has a more dialogical than polarizing profile, Mundo (2019). Jones M. (2019) finds that 'practically all Argentines support President Alberto Fernández's efforts to protect Argentina from the new coronavirus'. He makes use of Twitter daily and has more than two million followers.

Justin Trudeau - Prime Minister of Canada - is a teacher, leader, and defender of youth, elected by Liberal Party in 2015 and reelected in 2019. He studied literature at McGill

\footnotetext{
${ }^{9}$ Political philosophy of the late Néstor Kirchner, president of Argentina from 2003 to 2007, and of his wife, Cristina Fernández de Kirchner, president of the country from 2007 to 2015.
} 
University, graduating with a Bachelor of Arts (BA). Justin Trudeau emphasizes fair economic opportunities for all, respecting and promoting freedom and diversity for a more democratic government, Canada (2019), acting as a protagonist in the combat communication of COVID19 in his country. After going through the first wave of the virus, he considered that the resumption should be made "with great care, based on the best scientific advice, until there is an appropriate treatment or a vaccine'. Canada was one of the first countries to vaccinate against COVID-19, Newton (2020). Justin Trudeau has more than five million followers on Twitter.

According to Mergel (2013), bidirectional public online interactions are an innovative form of government agencies' communication. In this work, we measure and analyze the Top10+ (10 most liked messages) of heads of government, via Twitter, focusing on those dealing with COVID-19. In addition, we relate to the increase/decrease in deaths caused by the disease in each country. In general, we investigate the nature of the impact that social media interactions have had on governments and whether these measures were effective in the communication processes, including different public opinions.

\section{CORRELATED WORKS}

For governments, social media applications offer the opportunity to integrate information and opinions from citizens to assist innovatively in the policy-making process; to increase transparency by sharing information on social media channels; to collabo- rate with the public and prepare decisions or create solutions to government problems Mergel (2013).

Several authors have studied the topic and developed different approaches and methods to assess networks' role and their use. Castells (2017) gives examples of the Arab Spring demonstrations in 2010 and the Occupy Wall Street movement in 2011. Mathur, Kubde, and Vaidya (2020) used Twitter data to analyze across the world the mental health of people during the COVID-19 pandemic situation through emotion analysis and classified it into basic emotions. The idea is via their analysis, authorities can better understand the mental health of the people and update the content accordingly. Waisbord and Amado (2017) analyzed the use of Twitter by populist presidents in Latin America. They identified that the platform was not used to promote a dialogue between presidents and the public or to change conventional presidential communication practices. Instead, it was identified that populists used Twitter to counter criticism from journalists, to put their points of view, but not to promote direct communication with citizens or to listen to their ideas. 
The research conducted by Mergel (2013) indicates that the American government, at this point, still has little experience in extracting knowledge from the exchange of messages on social media sites. In contrast to the doubts of Mergel (2013), more recent studies also show that the political space found in social media a favorable environment to legitimize ideological discourses with the increasing purpose of leveraging more followers.

In another line of investigation, there is evidence that social media have been instrumental as a channel of communication in electoral campaign times, especially for heads of government. The authors Groshek and Koc-Michalska (2017) credited Barack Obama's campaign successes, in part due to his experience in social media, in 2008 and 2012. In his study, Kreis (2017) showed how USA President Donald Trump employed Twitter as a strategic power politics tool to spread his right-wing populist discourse. Nai (2020) deepened his studies in discourse analysis and investigated how messages are interpreted when the public is for or against a government head. The study of Nai (2020) used change and Donald J. Trump posts on this subject.

In a negative way, the space in which Populism found echo represents an even more significant challenge: misinformation. Social media has become an open way to spread a flood of fake news. According to Cherilyn I (2018), finding ways through contemporary information challenges is of utmost importance to society, including governments, Internet companies, educators, and non-governmental organizations (NGO).

According to the report of Gruzd and Mai (2020), Twitter in Canada is in the second most accessed social media group as a source of information about COVID-19. Sixty- seven percent of respondents who consume information stated that they 'sometimes' or 'more often' get information from Twitter.

The key issue of this research is to identify initially if occurred, through Twitter, communication of the heads of government of the American continent's countries with their audience during the pandemic with messages, verifying whether the most liked messages dealt with COVID-19. Then, to examine the communication that occurred at the peak of the disease, check whether there was direct interaction with the public, and whether this interaction generated a passive communication of sharing, strengthening the ties between governments and their citizens.

When it comes to speeches on social media, we must not forget that the Populism practiced by heads of government in the American continent countries was a strong legacy of the 20th century and that it has also been present in the political sphere of the contemporary world. This article aims to verify whether there is a relationship between more populist attitudes 
of these heads of government with more active communication on Twitter and how this practice impacts and strengthens the discourse on COVID-19. In recent studies, Groshek and KocMichalska (2017), De Vreese, Esser, Aalberg, Reinemann, and Stanyer (2018) and Fernández García and Salgado (2020) addressed concepts or the relationship Populism vs. Electoral process. These authors discussed theories and argued about populist impacts and actions, widely followed by traditional and social media. Fernández García and Salgado (2020) considers a gap in Populism research that tends to focus only on politicians and not on people. Our research also examines whether the heads of government considered populist were successful ${ }^{10}$ in communicating via Twitter about COVID-19 measures with their audience.

It is also important to identify patterns that may point to the dissemination of false content or that may suggest an action of negative use of the networks. In this case, we investigate whether Populism (from the analysis of the amount of tweets) and misinformation (from the study of works in the literature) directly impact the deaths of COVID-19 in the countries analyzed. We agree with Ryabchenko and Malysheva (2017) when these authors warn of possible inappropriate use of Social Media in the political-social sphere.

It is worth mentioning yet another result from Ryabchenko and Malysheva (2017). These authors consider that the recent political and social events characteristic in each country, as well as the different political regimes, made evident the need for a new look at the influence of information and communication technologies in the public sphere. The search for works related to Social Media, Presidents and Politics allows locating 220 documents in a query in the Scopus scientific database to reinforce the interest in the subject. Among these documents, there is an annual increase in publications from 2017 onwards, with 17, 20, 30, and 1 (until January $15,2021)$ documents recovered, respectively. Figure 1 shows the networks of occurrence of words extracted from the abstracts of these 220 documents, including the search string 'tweet' and 'twitter', the most used social media platform in this case. By restricting the search, replacing social media with Twitter, 32 documents are located, indicating an annual increase in the number of publications with this platform, from 2016 to 2021, with 2, 7, 10, and 1 (until January 15, 2021) studies published, respectively.

In the lexical similarity analysis graph Thijs and Glänzel (2018) of Figure 1(a) - built with VOSviewer (2020) - the nodes represent the words and the size of these nodes represents the number of co-occurrences. The distance between two nodes establishes the identified proximity between them: a shorter distance usually indicates a stronger relationship. By default,

\footnotetext{
${ }^{10}$ That president who uses Twitter as an information tool is considered successful.
} 
network nodes are organized into clusters displayed in different colors that allow you to identify the cluster to which a node has been assigned. Thus, a cluster is a set of closely related nodes. It appears that the nodes 'twitter' and 'tweet', highlighted in Figure 1 (b), are part of the same red cluster and are connected to 'fake news', 'election' and 'trump'. In the green cluster, the 'brazil' node appears associated with 'world', 'process', 'population', 'work', 'human right', 'woman'. Finally, it is worth highlighting the network of two other countries analyzed in this article, Mexico and the United States, both belonging to the blue cluster. The 'mexico' node connects more closely with 'nation' and 'culture'. In contrast 'united states' connects with 'war', 'percent', 'child', 'education' and 'value'.

\section{MATERIALS AND METHODS}

A sequence of steps was established to analyze the Twitter profile of each head of government. Figure 2 presents a schematic diagram of the methodology employed, in which three macro steps are highlighted, indicated by different colors: data collection, quantitative analysis, and qualitative analysis.

Figure 1 - (a) Lexical similarity analysis of the most recurrent terms in Scopus database documents (a), and (b) highlighting the term Twitter as a Social Media Platform.

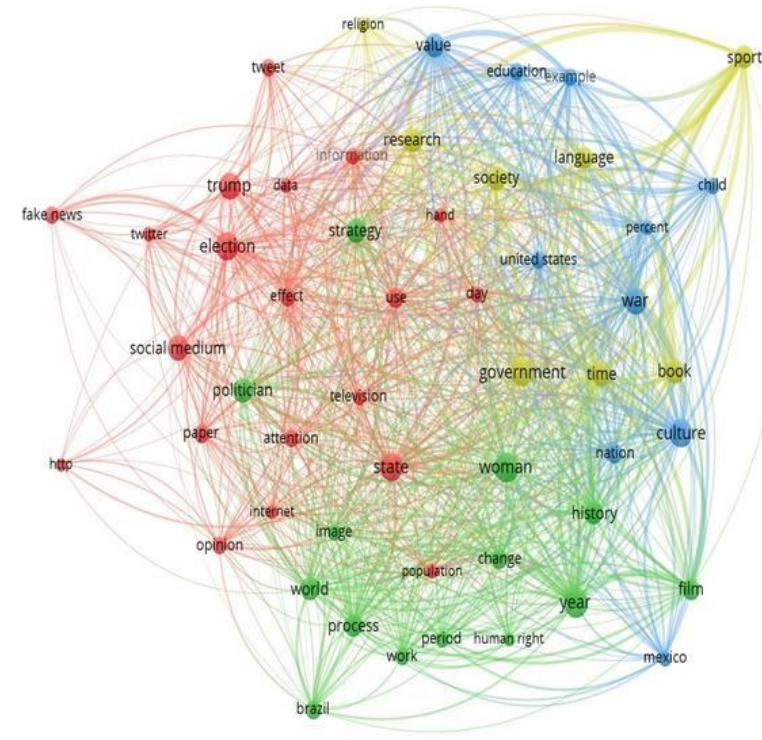

(a)

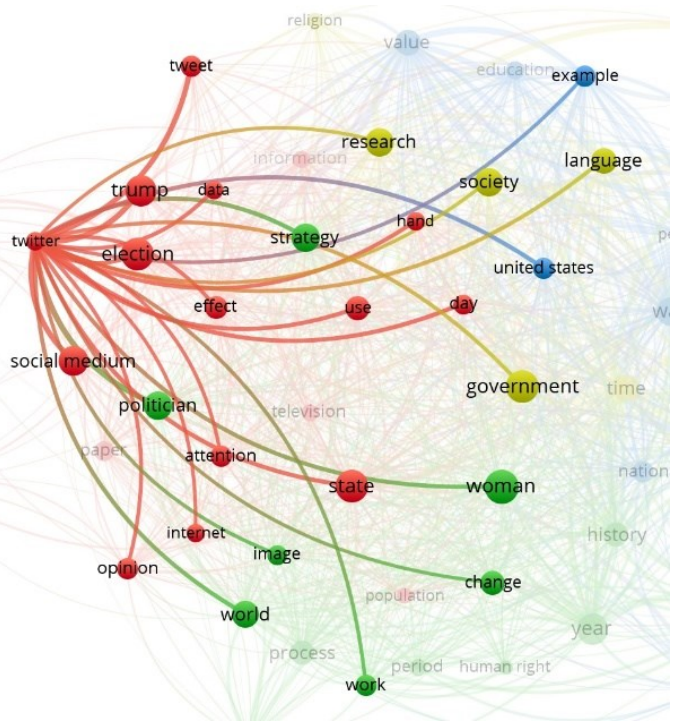

(b)

Source: Developed on VOSviewer (2021) 
Figure 2. Flowchart of the Methodological Process

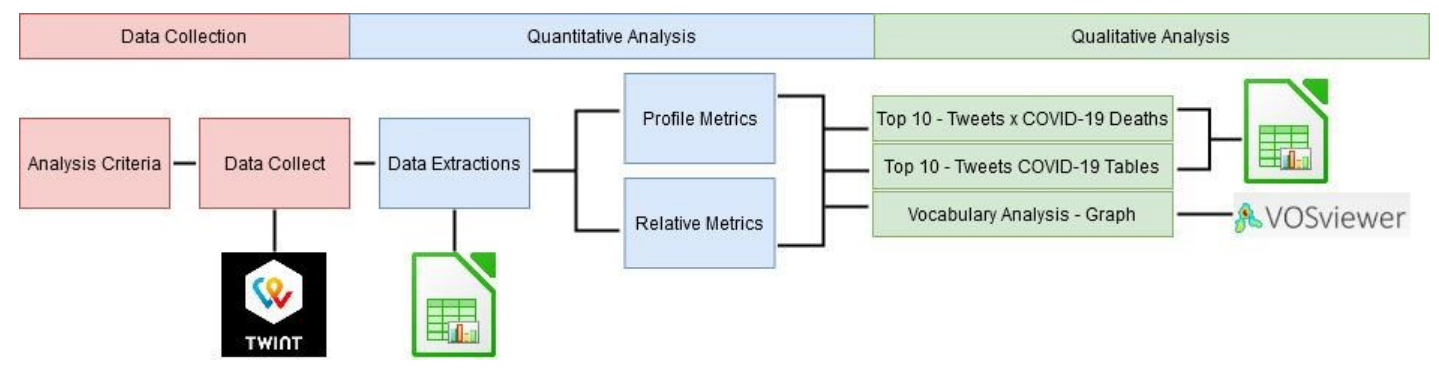

Source: Authors (2021)

The general purpose of this work is to analyze metrics related to the behavior and activities of heads of government on Twitter social media, showing characteristics of interaction with their audiences, as well as the type of content most popularly disseminated by these heads of government in their profiles. Thus, it is essential to use tools that enable the analysis of the use of social networks, starting from the data collection process to the graphic visualization phase, so that the results can be discussed.

In the Analysis Criteria stage, Twitter profiles of heads of government of countries in South and North America that had posting activities from November 2019 to November 2020 were chosen. To establish a comparative of social and institutional presence were used SNA, Lutu (2019); Recuero, Soares, and Gruzd (2020) and webometric tech- niques. The latter allows qualitative data analysis and include quantitative research methods to analyze the content collected from Twitter, Khan, Yoon, and Park (2014).

In the Data Collect step, the Twint tool, Twint Project (2017), was used. Twint is an advanced tool written in Python that allows for scraping Tweets from Twitter profiles without using Twitter's Application Programming Interface (API). This tool has been used in other similar researches, such as in Narayanrao and Kumari (2020), in which data extraction is performed to predict tweets that have depressive content, in addition to Chamby-Diaz and Bazzan (2019), where the detection of transport traffic events is performed using machine learning models.

Data Collect processing resulted in a large database in CSV (Comma-separated values) format. Then, Data Extractions were carried out, with the purpose of organizing the data, discriminating metrics that will be addressed in the following sections, which are: id; conversation_id; created_at; date; time; timezone; user_id; username; name; place; tweets; language; mentions; urls; photos; replies count; retweets count; likes count; hashtags; cashtags; link; retweet; quote url; video; thumbnail; near; geo; source; user_rt_id; user_rt; retweet_id; reply_to; retweet date; translate; trans_src; trans_dest. 
Data Extractions originated Profile Metrics, and these were used in the initial quantitative analysis. The most important quantitative analysis metrics were: created at, username, tweets, language, mentions, retweets count, likes count, and hashtags. The metrics of followers and followings directly from the social network were also analyzed, respectively, indicating the total number of profiles followed by a head of government and the total number of profiles followed by the head of government. This stage results' are presented in Table 1, with the proposal to answer questions such as: how close is the head of government to his audience? What is the degree of networking or passive communication between the head of government and the public? Which heads of government publish the most? Which heads of government have the most followers? After extracting the data in Profile Metrics, a complementary quantitative analysis based on Relative Metrics was performed. The purpose of these calculations is to verify if the values obtained in Table 1 are significant when compared with other metrics of each head of government analyzed, such as the size of the country's population that governs, the number of followers, total tweets, etc. Thus, it is possible to make a more consistent analysis, given that certain heads of government use Twitter profiles to propagate government and/or personal information, as well as some profiles, even if they belong to the head of government, are administered by advisors. In this way, a more detailed analysis can qualify this social presence. Table 2 presents the results generated by the equations proposed in this article.

Table 1. Profiles analyzed from November 2019 to December 2020.

\begin{tabular}{|c|c|c|c|c|c|c|c|c|c|c|}
\hline Country & Profile & Total de Tweets & Followers & Followings & Retweets & Total Likes & Top10+ & TM & TH & TMP \\
\hline Argentina & @alferdez & 981 & $1,979,659$ & 7.223 & $2,276,823$ & $12,477,319$ & $1,445,009$ & 337 & 63 & 224 \\
\hline Mexico & @lopezobrador_. & 677 & $7,663,379$ & 255 & $2,109,686$ & $7,538,992$ & 460,511 & 0 & 58 & 0 \\
\hline Venezuela & @icolasMaduro & 2,286 & $3,856,337$ & 94 & $5,253,528$ & $4,513,187$ & 145,012 & 243 & 581 & 74 \\
\hline Colombia & aIvanDuque & 2,296 & $2,104,222$ & 1793 & $1,085,607$ & $3,519,592$ & 320,167 & 1.360 & 2.104 & 389 \\
\hline Bolivia & Q.JeanineAnez & 1,240 & 354,056 & 473 & 330,555 & $1,926,894$ & 250,761 & 140 & 22 & 87 \\
\hline Ecuador & QLenin & 932 & $1,066,898$ & 41 & 998,707 & $1,388,404$ & 101,690 & 495 & 973 & 232 \\
\hline Paraguay & CMarito $A$ bdo & 605 & 588,822 & 625 & 135,826 & 576,041 & 125,279 & 127 & 402 & 55 \\
\hline Peru & @MartinVizcarraC & 171 & $1,266,117$ & 491 & 11,766 & 106,194 & 75,137 & 61 & 61 & 44 \\
\hline USA & QrealDonaldTrump & 6,021 & $88,623,324$ & 51 & $131,563,660$ & $595,984,877$ & $9,502,029$ & 1.769 & 575 & 651 \\
\hline
\end{tabular}

From the quantitative analysis, additional processing was carried out so that the results could be better understood and discussed qualitatively. Thus, the construction of curves that relate the Top10+- Tweets x COVID-19 Deaths - to each of the countries analyzed was made. The purpose was to qualitatively identify the ten most liked posts from each profile of heads of government. Two questions could then be answered: (i) which of these most liked tweets are related to COVID-19? (ii) at what point in the disease death curve in the country were these 
tweets posted? This last question was answered for Brazil and Canada, in Figure 3. This step's processing allowed the generation of tables of the Top10+- Tweets x COVID-19 (Tables 4, 5 and 6). Figure 4 illustrates the consolidation of this data.

With the complete database containing all the tweets published in the heads of government profiles, it was possible to carry out the Vocabulary Analysis - Grap stage, whose objective is to analyze the subjectivity of the word cloud generated in the profiles. Besides, answering questions such as: Did the head of government use the profile to help effectively fight the pandemic? What were the main words mentioned in the collected vocabulary?

In this step, VOSviewer version 1.6.15, VOSviewer (2020), was used, a tool capable of forming and visualizing maps from different sources of textual data based on co- authorship relations, co-citation, bibliographic coupling, citation and co-occurrence, making use of network layout and network clustering, allowing layout adjustments and clustering with different metrics, including natural language processing techniques, indicating that relevant and non-relevant terms can be distinguished algorithmically. VOSviewer was chosen due to its ability to visualize the relationship between keywords in the analyzed tweets, as also used in Purnomo, Agustina, Septianto, Prasetyo, et al. (2020). Figures 5 and 6 illustrate the word clouds generated in this graphical analysis.

Vizcarra Cornejo presided over the country between March 2018, when the then President resigned, and November 2020, when the Peruvian Congress impeached him. Jeanine Añez Chavez presided over Bolivia between November 2019 and November 2020, in an interim manner after the resignation of Evo Morales, at a time of political instability. With a conservative profile, she received immediate international support from countries under rightwing governments, such as Brazil, as soon as she proclaimed herself President.

\section{RESULTS AND DISCUSSION}

\subsection{GENERAL PROFILES ANALYSIS}

The Table 1 presents, in columns 1 and 2, the country's name and the official profile of the President or Prime Minister. The 'Total Tweets' column indicates the number of tweets sent in the analysis period (from November 2019 to November 2020), while 'Followers' and 'Followings' represent the numbers of followers and followed by the head of government. The 'retweets' column indicates the number of times that a message published by the profile owner was resent by another user. 'Total Likes' and 'Top10+' are the total likes that the Presidents and the Prime Minister received in the period's posts and the ten most liked posts, respectively. 
The 'Total of Mentions' (TM) is the total number of mentions that the head of government (Outdegree) made in all his publications during the analyzed period, and the same profile can be mentioned by them several times. The 'Total of Mentioned Profiles' (TMP) corresponds to the number of different profiles that the President or the Prime Minister mentioned in the period. The 'Total of Hashtags' (TH) is the total amount of hashtags that the head of government used in the period, and the same hashtag can be present in several publications of the same profile.

Individual profiles of a network are important structures that reveal individual and group identity characteristics. In this research, we adopted the metrics of Degree of Centrality OutDegree $^{11}$ to verify the activity of the main actors in each analyzed network. To measure the degree of OutDegree are adopted the metrics highlighted by Recuero, Zago, and Soares (2019), Lutu (2019) and Kusen and Strembeck (2018). In short, when a user mentions or retweets someone, there is a connection produced through that tweet.

It can be seen from the Table 1 that former President Donald Trump (USA) presents much higher values for almost all metrics. This is due, mainly, to the expressive amount of followers (greater volume of followers) that he had ${ }^{12}$ compared to the other profiles.

However, the former USA President had the second lowest value of Followings (51), although the former President aimed to get closer to the public, indicated by the highest values of TM $(1,769)$ and TMP $(651)$, among those presented in Table 1, by mentioning several times other profiles, many times of supporters. In addition to Donald Trump (USA), Jair Bolsonaro (Brazil), Ivan Duque (Colombia), and Justin Trudeau (Canada) also present this characteristic, highlighting the profile of the President of Brazil, who has one of the smallest TMP.

In contrast, the profile of President Andrés Manuel López Obrador (Mexico), who belongs to the Movimiento Regeneración Nacional (MORENA) and who was elected in 2018 by the left alliance 'Junto Haremos Historia', does not mention other profiles, nor does it mention other publications, leading to the belief that the profile is not used for the personal opinions of the president. This suggests that there is no interest in more direct interaction with the public. Mention-based studies can provide more information about influencers than SNA based on 'followers', Lutu (2019).

Another highlight pointed out in Table 1 is the president Jair Messias Bolsonaro (Brazil), who presented a small TH (4). This value represents a small use of hashtags, having

\footnotetext{
${ }^{11}$ The number of outward-directed graph edges from a given graph vertex in a directed graph.

12 The data used in this analysis were collected before Jan 8, 2021, date that there was the definitive exclusion of the former President Trumps account by Twitter.
} 
as reference the President Ivan Duque Márquez (Colombia), elected in 2018 by the Centro Democrático Party, which presents the largest number of hashtags $(2,104)$ in his tweets in the period under analysis. Another profile that draws attention is that of president Miguel Juan Sebastián Piñera Echenique (Chile), elected in 2017 by the 'Coalition for Change' that brings together the Chilean right-wing parties assumed his second term in 2018, with the highest number of 'Followings' $(19,900)$, contrasting with that of the President of Lenín Moreno Garcés Boltaire (Ecuador), who was elected in 2017 by the 'Alianza PAIS', which has the lowest value of 'Followings' (41).

One cannot fail to consider that Donald Trump has the highest retweets value, indicating active participation of followers, accompanied by Jair Bolsonaro, with a value 13 times lower in this metric when compared to the USA President. Also, Trump has approximately 10.5 times more likes than the president of Brazil, second in the number of likes.

\subsection{GENERAL PROFILES ANALYSIS}

Once the questions made in the first part of the methodology were answered, with the quantitative analysis of Table 1, additional metrics were defined. This is because the values indicated in Table 1 can be related to several factors, such as the time the account is active, the engagement of followers, and even exogenous factors, such as the size of these countries' population.

Thus, a complementary quantitative analysis requires the evaluation of other metrics in addition to those presented in Table 1. Table 2 presents relativized results of the metrics observed in Table 1. For the composition of these metrics, some relations are proposed.

FP (Follower per Population) indicates the proportion of the number of Followers by the size of the country's population of each head of government, using the Followers metrics in Table 1 and the population size indicated in the second column of Table 2, according to Equation 1.

$$
F P=\text { Followers } \div \text { Population Size }
$$

RF (Retweets per Follower) calculates the ratio of retweets divided by profile follower, using the Retweets and Followers metrics of Table 1, according to Equation 2.

$$
R F=\text { Retweets } \div \text { Followers }
$$

LT (Likes per Tweet) is the proportion of likes per tweets (publication) posted, obtained using the Total Likes metric from Table 1 and the total number of publications made by the profile, according to Equation 3. 


$$
L T=\text { Total Likes } \div \text { Total Tweets }
$$

LF (Likes per Follower) corresponds to the value obtained from the number of likes per follower, being obtained through the Total Likes and Followers metrics of Table 1, following Equation 4:

$$
\text { LF }=\text { Total Likes } \div \text { Followers }
$$

TMT (Total of Mentions per Tweet) is the Total of Mentions divided by the total of Tweets posted, observed in Table 1, calculated by Equation 5.

$$
T M T=\text { Total Mentions } \div \text { Total Tweets }
$$

TMPT (Total of Mentioned Profiles per Tweet) is the proportion of Total Profiles Mentioned by the total of Tweets posted, observed in Table 1, according to Equation 6.

$$
\text { TMPT }=\text { Total Mentions Profiles } \div \text { Total Tweets }
$$

The results of Table 2 suggest that, even considering the number of Followers weighted by population size, the profile of the former USA President stands out with $0.2677 \mathrm{FP}$, followed by the profiles of the Prime Minister of Canada (0.1429), of the President of Venezuela (0.1356) and of the President of Chile (0.1308), which present similar relative values, but of the order of $46 \%$ lower.

Table 2. Relative evaluations of metrics from November 2019 to December 2020.

\begin{tabular}{cccccccc}
\hline Country & Population Size & FP & RF & LT & LF & TMT & TMPT \\
\hline USA & $331,002,651$ & 0.2677 & 1.4845 & $98,984.3675$ & 6.7249 & 0.2938 & 0.1081 \\
Brazil & $212,559,426$ & 0.0315 & 1.4395 & $22,750.0541$ & 8.4244 & 0.6858 & 0.0561 \\
Argentina & $45,195,774$ & 0.0438 & 1.1501 & $12,718.9796$ & 6.3028 & 0.3435 & 0.2283 \\
Mexico & $\mathbf{1 2 8 , 9 3 2 , 7 5 3}$ & 0.0594 & 0.2753 & $\mathbf{1 1 , 1 3 5 . 8 8 1 8}$ & $\mathbf{0 . 9 8 3 8}$ & 0.0000 & 0.0000 \\
Canada & $37,742,154$ & 0.1429 & 0.2057 & $2,039.9014$ & 1.2088 & 0.4469 & 0.1336 \\
Venezucla & $28,435,940$ & 0.1356 & 1.3623 & $1,974.2725$ & 1.1703 & 0.1063 & 0.0324 \\
Colombia & $50,882,891$ & 0.0414 & 0.5159 & $1,532.9233$ & 1.6726 & 0.0592 & 0.1694 \\
Bolivia & $11,673,021$ & 0.0303 & 0.9336 & $1,553.9468$ & 5.4123 & 0.1129 & 0.0702 \\
Ecuador & $17,643,054$ & 0.0605 & 0.9361 & $1,489.7039$ & 1.3013 & 0.5311 & 0.2489 \\
Uruguay & $3,473,730$ & 0.0094 & 5.2785 & $3,994.9333$ & 29.3826 & 0.2500 & 0.1250 \\
Chile & $19,116,201$ & 0.1308 & 0.0791 & $1,875.8618$ & 0.2767 & 0.2141 & 0.1518 \\
Paraguay & $7,132,538$ & 0.0826 & 0.2307 & 952.1339 & 0.9783 & 0.2099 & 0.0909 \\
Peru & $\mathbf{3 3 , 0 5 0 , 3 2 5}$ & 0.0383 & 0.0093 & 621.0175 & 0.0839 & 0.3567 & 0.2573 \\
\hline
\end{tabular}

When observing the RF, the profile of President Luis Alberto Lacalle Pou (Uruguay), elected in 2019 by center-right parties, is highlighted, indicating that the small number of followers, retweets a lot of the posts made. It is noteworthy that he took office on March 1, 2020, that is, thirteen days before the first cases of COVID-19 were reported in the country.

For the LT, the USA stands out again, followed by Brazil, Argentina, and Mexico. It should be noted that the difference between the USA and Brazil (first and second in the ranking 
of this item) is of the order of 4.35 times, that is, even considering the total of tweets, Donald Trump's profile was the one with the highest number of likes. Uruguay stands out, being approximately 3.49 times bigger than the second place (Brazil) in LF.

Regarding the TMT, the highlights are Brazil's President with the highest value (0.6858), and the profile of the President of Mexico, with a value equal to zero. While for the TMPT, the Presidents of Peru with the highest value and again Mexico with the value of zero are highlighted.

The Total Tweets Table 1 and FP Table 2 can be used to identify populist heads of government. Considering only these metrics, the USA is again ahead of other countries, followed by Canada by far, both in number of tweets and in FP. Mexico has the second-largest number of followers, but has a low number of tweets and makes no mention (TM). Thus, it could not be considered by these metrics as populist.

\subsection{RELATIVIZED RESULTS CONSIDERING COVID-19}

Considering the global pandemic scenario, the values obtained in Tables 1 and 2 were compared with Table 3. Statistical data on the impact of COVID-19 on the population of each country are shown, with the following information: PS (Population Size) pointing out the population size; TD (Total Deaths) referring to the total deaths due to COVID-19; TI (Total Infected) showing the total of infected by COVID-19; PDI (Percentage of Deaths by Infected) specifying the percentage of deaths of infected by COVID-19; PIP (Percentage of Infected Population) indicating the percentage of the population infected by COVID-19; and PDP (Percentage of Deaths in the Population) informing the percentage of deaths in the population due to COVID-19.

According to Table 3, Uruguay was one of the least affected countries with COVID- 19 in terms of deaths, percentage of contaminated people in the population, and per- centage of deaths by infected people. Mexico, which had one of the highest percentages of deaths by infected people, was one of the countries with the lowest LF index (Table 2). The TMT indicator also points out that the Mexican representative (Lopez Obrador) did not make any mention during the pandemic period, despite being considered a left-wing populist, has not been successful in fighting the Pandemic in his country Agren (2021) and, until the moment of this survey, has not used the resources of Twitter to establish more active communication with its public. 
Table 3. COVID-19 data from November 2019 to November 2020.

\begin{tabular}{ccccccc}
\hline Country & PS & TD & TI & PDI & PIP & PDP \\
\hline Argentina & $45,479,120$ & 38,730 & $1,424,533$ & $2.72 \%$ & $3.13 \%$ & $0.09 \%$ \\
Bolivia & $11,639,909$ & 8,957 & 144,708 & $6.19 \%$ & $1.24 \%$ & $0.08 \%$ \\
Brazil & $211,715,968$ & 173,120 & $6,335,878$ & $2.73 \%$ & $2.99 \%$ & $0.08 \%$ \\
Canada & $37,694,084$ & 12,147 & 381,557 & $3.18 \%$ & $1.01 \%$ & $0.03 \%$ \\
Chile & $18,186,770$ & 15,410 & 551,743 & $2.79 \%$ & $3.03 \%$ & $0.08 \%$ \\
Colombia & $49,084,840$ & 36,766 & $1,316,806$ & $2.79 \%$ & $2.68 \%$ & $0.07 \%$ \\
Ecuador & $16,904,868$ & 13,461 & 192,685 & $6.99 \%$ & $1.14 \%$ & $0.08 \%$ \\
Mexico & $128,649,568$ & 105,940 & $1,113,543$ & $9.51 \%$ & $0.87 \%$ & $0.08 \%$ \\
Paraguai & $7,191,685$ & 1,756 & 82,424 & $2.13 \%$ & $1.15 \%$ & $0.02 \%$ \\
Peru & $31,914,988$ & 35,923 & 962,530 & $3.73 \%$ & $3.02 \%$ & $0.11 \%$ \\
Uruguai & $3,387,605$ & 77 & 5,857 & $1.31 \%$ & $0.17 \%$ & $0.00 \%$ \\
US $\Lambda$ & $332,639,104$ & 268,045 & $13,541,221$ & $1.98 \%$ & $4.07 \%$ & $0.08 \%$ \\
Venezuela & $28,644,604$ & 897 & 102,394 & $0.88 \%$ & $0.36 \%$ & $0.00 \%$ \\
\hline
\end{tabular}

*https://www.indexmundi.com/factbook/fields/population

**https://ourworldindata.org/coronavirus-source-data

It is also worth noting that the number of tweets (677) is very unrepresentative compared to other countries and, consequently, suggests that Twitter is not the main platform for institutional communication/representation.

On the other hand, the TMT metric positions the President of Brazil as the one who made the most mentions to users, but is one of the least diversified of the mentioned profiles, indicating that it restricts his comments to a specific set of users. This passive communication of quotations and sharing reinforces the formation of bubbles of ideological filters. In President Jair Bolsonaro, the TMT indicator indicates a heavy use of Twitter to strengthen his populist discourse among his followers.

A similar situation was identified in the 2016 United States elections. The Groshek and Koc-Michalska (2017) survey found that social media acted as informational portals, often with false information shared by users. According to this study, this shared action helped Trump win the election by cultivating ideological filters bubbles.

Ecuador and Bolivia were two other countries with the second and third highest mortality rates due to COVID-19, considering the countries evaluated in this work. The TMPT metric indicates the diversity of profiles mentioned, with Peru, Ecuador, and Argentina standing out as the countries that most cite different profiles in messages. It is worth noting that Argentina has a strong tradition of using Social Media in political contexts. Slimovich (2016) identified in the presidential elections in Argentina, in 2011, the use of Twitter as a strategy to promote an interrelation with the mass media and the world of politics. 


\subsection{QUANTITATIVE ANALYSIS}

The relationship between the posts and elements of COVID-19 was identified from the data survey carried out, such as: combat speeches and the number of deaths in each country. Thus, trying to identify which profiles of government head use Twitter as an element that can help inform the population about the disease, for example.

\subsubsection{Narrative Analysis}

It is noted in Figure 3b that Jair Bolsonaro's most-liked tweet was close to the peak of the dead of COVID-19 in Brazil. In particular, 70\% of the most liked posts occurred in May November, 2020, when there was an intensification of Brazil's deaths. Similarly, in the profile of Prime Minister Justin Trudeau, 60\% of Top10+ are concentrated between March - July, the period in which the highest number of deaths occurred in Canada. Despite highlighting only the analysis of the heads of state of Brazil and Canada, the authors provide the charts for all the countries mentioned in this article, in Supplemental material.

Figure 3.(a) Top10+ of Justin Trudeau (Canada) vs COVID-19 deaths (b) Top10+ of Jair Bolsonaro (Brazil)vs COVID-19 deaths

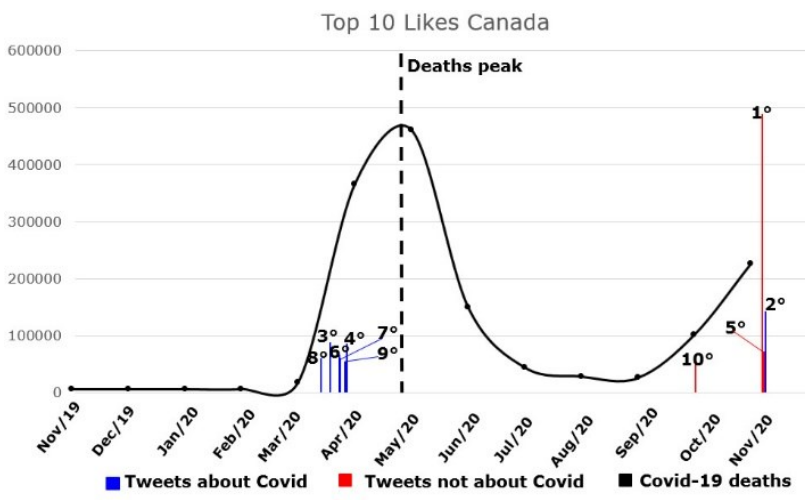

(a)

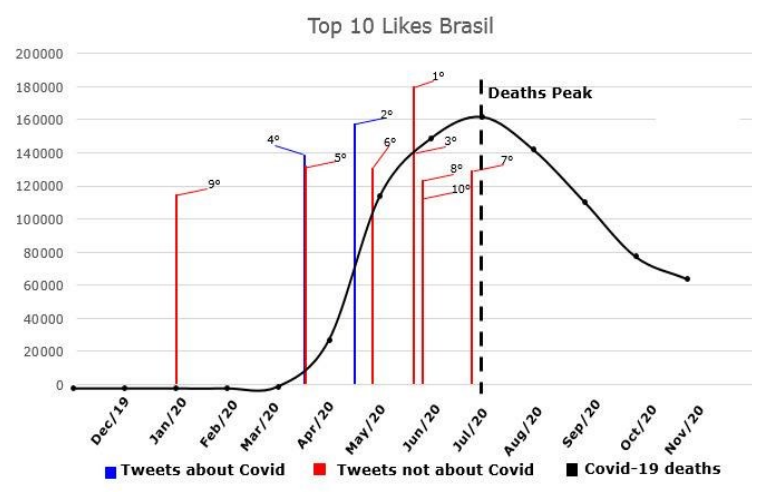

(b)

Source: Authors (2021)

The qualitative analysis of these graphs allows us to infer that the content of what was posted by the President of Brazil, for the most part, is not related to the fight against COVID19. More specifically, only two tweets from the Top10+ are related to COVID-19. Considering also the most liked post in the analyzed period, as indicated in Table 4, the President tweets the 
slogan of his 2018 election campaign, in June 2020, close to the peak of the number of deaths by COVID-19. Besides, the 7th most liked tweet occurred in the month of the peak of deaths from COVID-19, but it deals with a video about the inauguration of building work.

Table 4. Topl0+ of Jair Bolsonaro (Brazil).

\begin{tabular}{|c|c|c|c|}
\hline Ranking & Tweet: & Likes & About COVID? \\
\hline 1 & Brazil above all! & 179,725 & No \\
\hline 2 & $\begin{array}{l}\text { My solidarity with @gusttavo_lima singer, who has been unjust and cowardly } \\
\text { attacked after the great live that made inside your own home. He and other } \\
\text { sertanejos artists and other genres, have been great heroes in this fight against } \\
\text { COVID19 and deserve applause! }\end{array}$ & 157,691 & Yes \\
\hline 3 & $\begin{array}{l}\text { "moderation in the defense of true service rendered lie." We continue fighting } \\
\text { for Brazil and the Brazilian people, Good evening everyone! }\end{array}$ & 140,755 & No \\
\hline 4 & $\begin{array}{l}1 \text { inform you that my } 2 \text { test for COVID-19 gave NEGATIVE. - Good evening } \\
\text { everyone. }\end{array}$ & 138,611 & Yes \\
\hline 5 & $\begin{array}{l}\text { I never forsake the Brazilian people, for which I absolute loyalty! Good evening } \\
\text { everyone! }\end{array}$ & 131,682 & No \\
\hline 6 & $\begin{array}{l}\text { "Nothing in all creation, is hidden from God's sight. Everything is uncovered } \\
\text { and laid bare before the eyes of Him to whom we must give account." Hebrews } \\
\text { 4:13 - Good evening everyone! }\end{array}$ & 130,706 & No \\
\hline 7 & https://t.co/UWDT5vVKtr & 129,232 & No \\
\hline 8 & $\begin{array}{l}\text { View of citizens and have their homes invaded, for exercising their right freedom } \\
\text { of speech, a sign that something very serious is happening to our democracy! }\end{array}$ & 123,654 & No \\
\hline 9 & НАРРР 2020 ! & 114,327 & No \\
\hline 10 & $\begin{array}{l}\text { We are working on that faa enforce the right free expression in our country. } \\
\text { No guitar this principle should be accepted passively. }\end{array}$ & 112,372 & No \\
\hline
\end{tabular}

This shows that the President of Brazil does not use the social network to disseminate information that can help fight the disease. On the contrary, when using Twitter it is usually to misinform about the disease. In the research of Recuero et al. (2020) '[...] the president defended that COVID-19 was a "little flu", that things "should return to normal"', directly contradicting the Minister of Health, in addition to claim that chloroquine would be the "ccure" for COVID$19^{\prime}$.

On the other hand, the Prime Minister of Canada uses Twitter to disseminate news and mechanisms to combat COVID-19. Table 5 shows the positive posts to fight the disease, among the Top10+. As previously mentioned, the posts were made when Canada had the highest mortality due to COVID-19. 
Table 5. Top10+ of Justin Trudeau (Canada).

\begin{tabular}{|c|c|c|c|}
\hline Ranking. & Tweet & Likes & About COVID? \\
\hline 2 & $\begin{array}{l}1 \text { just spoke with a.JoeBiden, and congratulated him again on his election. } \\
\text { We've workod with each other before, and we're ready to pick up on that work } \\
\text { and tackle the challenges and opportunities facing our two countries - including } \\
\text { climate change and COVID-19. https://t.co/wldlwLSz5H }\end{array}$ & 141,634 & Yes \\
\hline 3 & $\begin{array}{l}\text { As you cope with the COVID-19 situation, we're focused on helping you get } \\
\text { through this. Here's what we're doing to support you. https: } / / \text { t.co/7Uujlre3all }\end{array}$ & 87,832 & Yes \\
\hline 4 & $\begin{array}{l}\text { Stay home. It doesn't matter that the wockend's almost here - if you choose to } \\
\text { gather in groups or hang out with your friends, you're putting yourself, those } \\
\text { around you, and our health care workers at risk. So take this seriously. Do the } \\
\text { right thing and stay home this woekend. }\end{array}$ & 81,553 & Yes \\
\hline 6 & $\begin{array}{l}\text { To the people who seem to think they're invincible: You're not. So go home } \\
\text { and stay home. You're not just putting yourself at risk, you're putting others } \\
\text { at risk too-nurses and doctors, grocery store workers, your grandparents, and } \\
\text { so many others. \#StayAtHomeSavelives }\end{array}$ & 65,431 & Yes \\
\hline 7 & $\begin{array}{l}\text { You need to stay home. And so do your friends and family members. } \\
\text { Help spread the word with your own video - and tag your friends to re- } \\
\text { mind them to stay home too. And together, we can \#PlankTheCurve. } \\
\text { aMichaelBuble and aVancityReynolds - can you help? \#StayAtHomeSave- } \\
\text { Lives https://t.co/fIPQQrzMIK }\end{array}$ & 59,759 & Yes \\
\hline 8 & $\begin{array}{l}1 \text { have some additional news to share this evening. Unfortunately, the results } \\
\text { of Sophie's COVID-19 test are positive. Therefore, she will be in quarantine } \\
\text { for the time being. Her symptoms remain mild and she is taking care of herself } \\
\text { and following the advice of our doctor. }\end{array}$ & 59,543 & Yes \\
\hline
\end{tabular}

It should also be noted that the narrative used by the Prime Minister of Canada is more detailed than that of the President of Brazil. Jair Bolsonaro, on several occasions, made posts from third parties, with shallow texts, as analyzed qualitatively.

In this regard, the behavior of the President of Argentina is also highlighted, who, despite having fewer posts than the President of Brazil (see Table 1), directs a large part of his posts to address issues related to COVID-19: 50\% of the 10 most liked tweets specifically address COVID-19, sometimes disclosing the recommendations of the World Health Organization (WHO), as seen in Table 6. The first records of Argentine presidential candidates on Twitter emerged in the 2011 elections. According to Slimovich (2016), most political figures in Argentina opened an account on Facebook ${ }^{13}$ or Twitter between 2009 and 2010. This reveals that, in Argentina, Twitter is a social media of common use in politics for communication with its public, as well as in several countries of America. All the Top10+ Tables of the heads of government mentioned in this article have been generated and are available on Supplemental material.

\footnotetext{
${ }^{13}$ www.facebook.com
} 
Table 6. Top10+ of Alberto Fernández (Argentina).

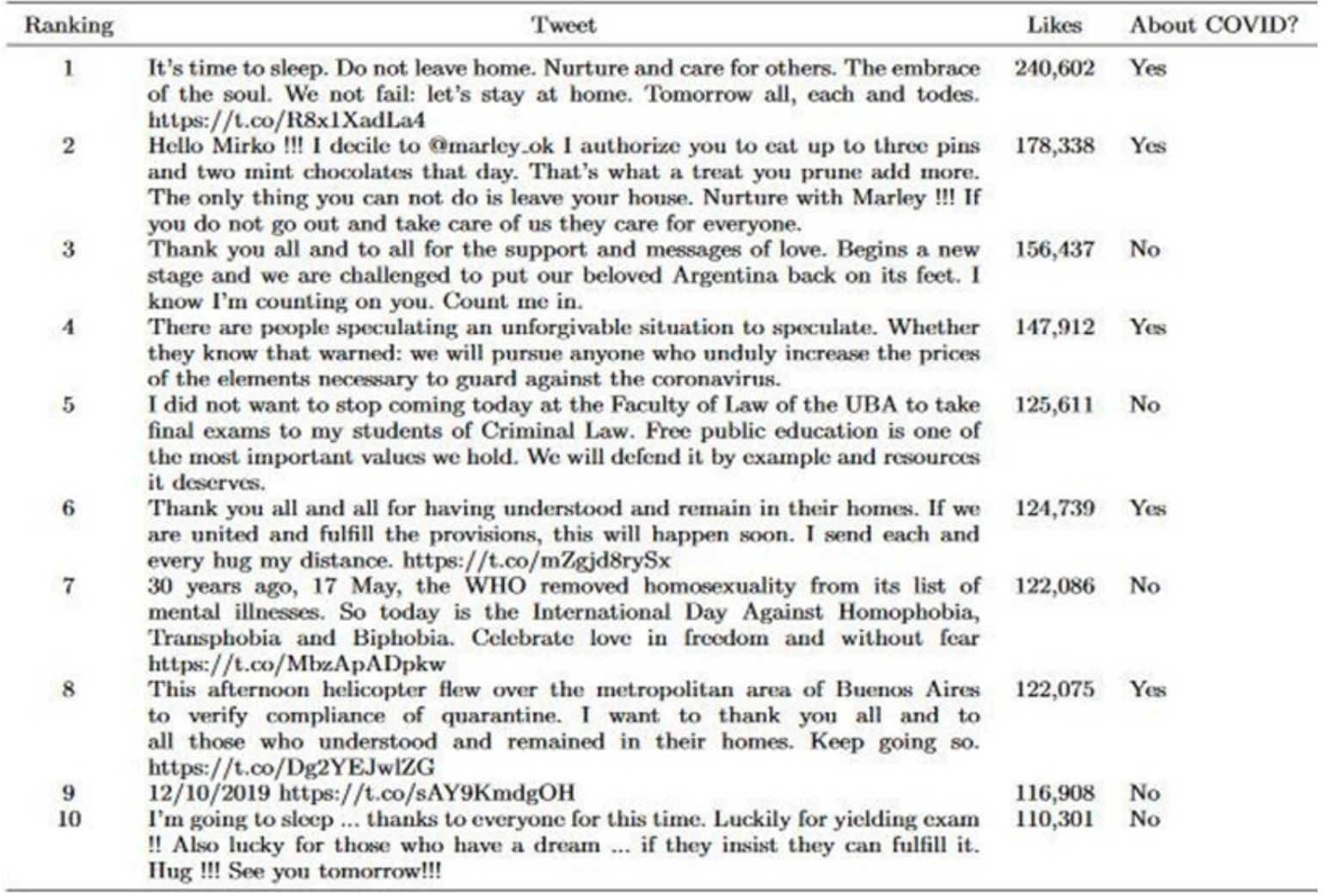

In order to summarize the Top10+ of the heads of government analyzed in this article, relating to the tweets that deal with COVID-19, Figure 4 is presented, containing absolute values and percentages. It is noted that the Prime Minister of Canada is the one who uses Twitter the most to send messages about COVID-19, unlike the profiles of presidents of Bolivia, Chile, and Mexico, who do not make any posts about it.

Justin Trudeau and Alberto Fernández are prominent in traditional media for their effective Twitter use in institutional communication. Dhillon (2016) notes that since Justin Trudeau was sworn in as Prime Minister of Canada, he has embraced social media, maintaining a robust online presence, especially on Twitter.

\subsubsection{Vocabulary Analysis}

Based on the preparation of the Tables of the profiles of the heads of government and their posts, containing the subjective elements of this study, a lexical analysis was carried out, aiming to identify narratives constructed from the most evident terms. This visualization was made with the VOSviewer software, as mentioned in Section 3. 
Figure 4. Tabulation of Top10+ vs. tweet about COVID-1

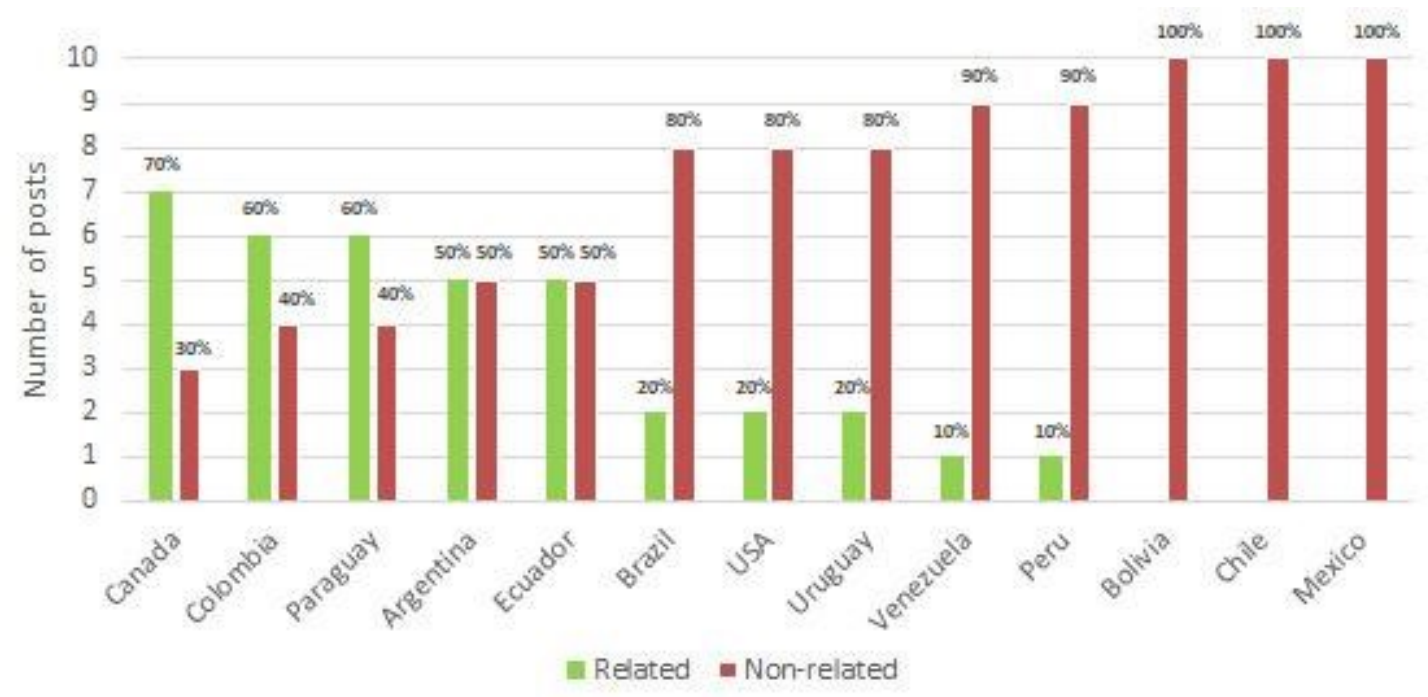

Source: Authors (2021)

It is noteworthy that these graphics were generated from all tweets of the heads of government profiles during the period of one year of research. Some profiles, such as the President Argentina profile, have few words in history, thus generating a low density graph.

Figure 5 presents the word cloud of the profile of the former President of the United States and the President of Brazil. In these clouds, it is possible to verify that there is no significant highlight for the pandemic's words. In the President of Brazil's profile, it is still possible to verify the word 'covid' and in smaller scale, 'pandemic'. However, these have less relevance than 'youtube' and 'work', for example.

Figure 5. Vocabulary of Trump and Bolsonaro profiles.
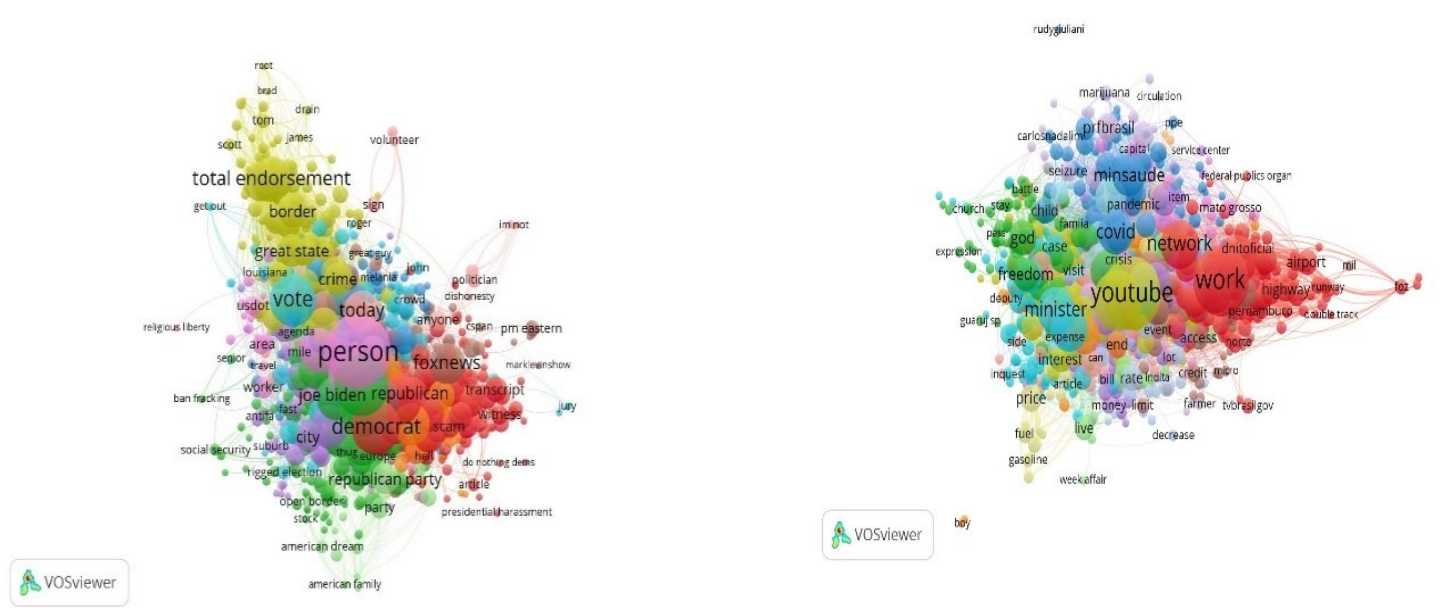

Source: Authors (2021) 
On the other hand, the vocabulary of Figure 6 (Canada and Colombia) contains several highlights for words focused on the fight against COVID-19, such as: 'vaccine', 'covid alert' and 'covid19'. In addition, an important word that can be highlighted in this cloud is 'prevencionyaccion', which was a hashtag used in social networks in Colombia to alert and motivate the population about the need for prevention and action against the new Coronavirus pandemic. Figures 5 and 6 show, therefore, the difference in vocabulary between the heads of government profiles. All the vocabulary graphs of all the heads of government mentioned in this article were generated and are available in Supplemental material.

Figure 6. Prime Minister of Canada and Colombia's Profile Word Cloud
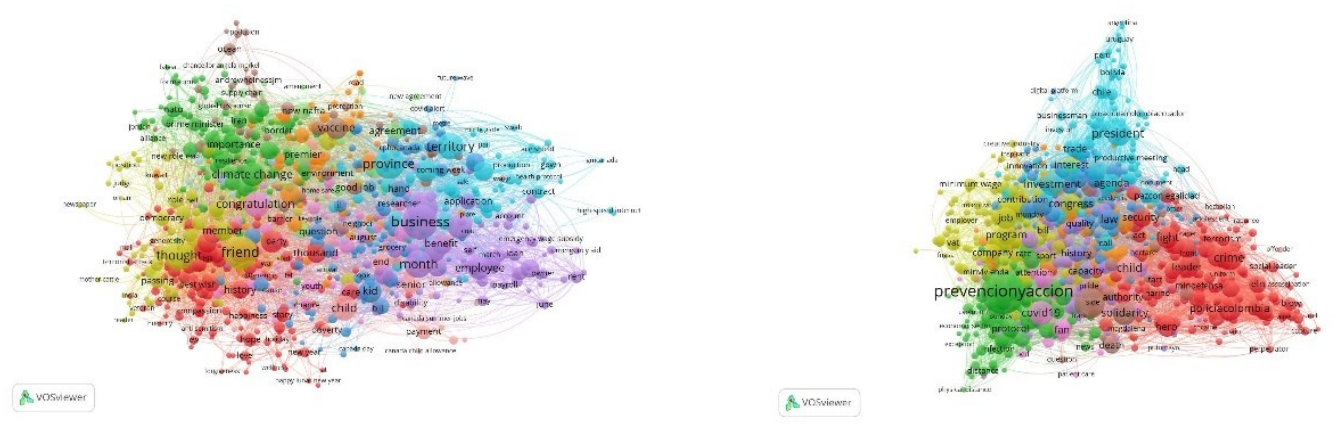

Source: Authors (2021)

\section{CONCLUSION}

The crisis caused by the new Coronavirus pandemic has demonstrated the value of reliable news and the challenges against disinformation. Research reveals the growing use of social media for the specific consumption of news about the pandemic. The potential of social media in engaging with the public caught the attention of former President Barack Obama's government in 2009, which signaled the use of new technologies at that time - social media to put information about its operations and decisions online and readily available for the public, Mergel (2013). Added to the use of social media in politics, a discussion about the populist posture of each government official and his social presence on Twitter. We did not identify in this research a direct relationship between the volume of communication on Twitter and the effectiveness in combating the pandemic, but the individual populist or non-populist positions of the government officials who realized the severity of the disease and had their communication to combat COVID-19 amplified on Twitter. 
This scenario of rising use of social media in the public, political, and governmental spheres motivated us to identify how heads of government in countries in South and North America communicated via Twitter during the COVID-19 pandemic. We follow methodological steps that are summarized in the planning and collection of data and analysis of quantitative data that measure categories and emphases in communication via tweets, retweets, likes and comments on matters relevant to the pandemic. We use SNA concepts and techniques related to OutDegree Centrality and Ego Networks to base our analysis on the behavior and activities on Twitter of the analyzed profiles. Besides, an analysis of qualitative data was carried out that sought to identify narratives about COVID-19, political interference, communication effectiveness in certain more severe times of the pandemic. Finally, graphs of the analyzed tweets' vocabularies were developed, from November 2019 to November 2020.

For general quantitative data, Donald Trump (USA) stands out with the highest rate in almost all quantitative criteria concerning the other heads of government, emphasizing retweets, likes, and followers. For number of Mentions (TM), a measure that may suggest a degree of proximity to its audience, a characteristic identified in the physical world in populist rulers. The TM $(1,769)$ and the TMP $(651)$ indicate that the former President of the United States mentioned several times other profiles and often his own supporters. This action strengthened the relationship he had with his audience. Behavior was also identified in the profiles of the Presidents of Brazil, Colombia, and the Prime Minister of Canada, who also present a high level of mentions, highlighting Jair Bolsonaro (Brazil), which has less diversity among the mentioned profiles, a situation that strengthens the ideals of an ideological bias, having its communication more directed to followers, having a low level of mentions of hashtags which demonstrates a strong Outdegree characteristic. Unlike the President Ivan Márquez (Colombia), who presents the highest number of hashtags $(2,104)$.

For the quantitative data that make a systemic relationship, we highlight the Pres- ident of Uruguay's profile, when observing the number of retweets per followers (RF), indicating that the small number of followers are engaged, retweeting the posts a lot. This behavior shows a strong relationship with his followers and confidence in the in- formation posted. For TMT (Total Mentions for total Tweets posted), Jair Bolsonaro stands out in the opposite direction of the president of Mexico, the latter, who in this criterion received a value equal to zero. When this systemic relationship takes the pandemic into account, we have the profile of Mexico's President, who used Twitter very little to communicate COVID-19 issues despite the fact that the country has one of the highest percentages of deaths by infected people. His government made use of only 677 tweets during the analysis period. 
A paradox was found when we performed qualitative analysis on the profile of Donald Trump. He had an excessive number of published Tweets, and Jair Bolsonaro with a large percentage in the total number of mentions by the total of posted tweets. We found that the two rulers used their popularity and efficiency in communicating with their audiences to deny the disease and disseminate false content on social media. We were remembering that the United States and Brazil configure as the countries with the highest number of deaths by COVID-19. In contrast, we have Canada with the third highest number of published tweets and tweets' highest recurrence on combating COVID-19. The latter country has one of the lowest death rates of the disease in relation to the population. Another highlight is the President of Argentina's profile, who even having fewer posts than others analyzed, directed much to deal with COVID- 19.

To finalize the research findings, we found in the vocabulary analysis that there are tweets related to COVID-19 in Justin Trudeau's profile, which is directly associated with his government's success in combating COVID-19. We have identified that a populist quality can help disseminate social media content and strengthen dialogue with the public. Thus, the problem is associated with each ruler's ideological bias, which in the case of the pandemic, was not always aligned with the precepts of science. Due to the volume of data with the number of countries analyzed, we limit our analyzes only to an approach of the degree of centrality Outdegree, considered sufficient to verify the role of each profile. For a more in-depth study, we intend to examine the degree of centrality InDegree to identify the impact that a profile has in promoting a more direct communication with its audience, being retweeted or mentioned in the tweets of other networks. Our research identified yet another passive communication between the government when there are retweets, likes, or a mention, but not precisely bilateral and direct communication.

For future work, we intend to add to this research data from Central American countries for a more global view of the Americas' countries. Additionally, apply technologies that can speed up a large-scale discourse or narrative analysis to identify clusters of ideologies, polarizations, and feelings. 


\section{REFERENCES}

AGREN, D. (2021, January 15). Amid pandemic's terrible toll, Mexico's Andres Manuel Lopez Obrador doubles down on austerity. The Globe and Mail. Retrieved from https://www.theglobeandmail.com/world/article-amid-pandemics-terrible-toll-mexicosandres-manuel-lopez-obrador

CANADA. (2019). Prime Minister Justin Trudeau. Retrieved from https://pm.gc.ca/en/primeminister-justin-trudeau

CASTELLS, M. (2017). Redes de indignação e esperança: movimentos sociais na era da Internet. Editora Schwarcz-Companhia das Letras.

CHAMBY-DIAZ, J. C., \& Bazzan, A. (2019). Identifying traffic event types from twit- terby multi-label classification. In 2019 8th Brazilian conference on intelligent systems (bracis) (pp. 806-811).

CHERILYN I, P., Julie. (2018). Journalism, fake news \& disinformation: handbook for journalism education and training. Unesco Publishing.

DE VREESE, C. H., Esser, F., Aalberg, T., Reinemann, C., \& Stanyer, J. (2018). Populism as an expression of political communication content and style: A new perspective. The international journal of press/politics, 23 (4), 423-438.

DHILLON, K. (2016, November 03). One year in, Justin Trudeau makes his mark on social media. CTV News. Retrieved from https://www.ctvnews.ca/politics/one-year-in-justintrudeau-makes-his-mark-on-social-media-1.3142825.

FERNANDEZ GARCIA, B.; SALGADO, S. (2020). Populism by the people: An analysis of online comments in Portugal and Spain. In International conference on social media and society (pp. 210-219).

GROSHEK, J.; KOC-MICHALSKA, K. (2017). Helping populism win? Social media use, filter bubbles, and support for populist presidential candidates in the 2016 US election campaign. Information, Communication \& Society, 20 (9), 1389-1407.

GRUZD, A.; MAI, P. (2020). Inoculating against an infodemic: A Canada-wide covid-19 news, social media, and misinformation survey. Social Media, and Misinformation Survey (May 11, 2020).

GUARDIAN, T. (2020, July 8). How Bolsonaro downplayed covid-19 before, and after, he contracted the virus - video. The Guardian. Retrieved from https://www.theguardian.com/world/video/2020/jul/08/how-bolsonaro-downplayed-covid-19before-and-after-he-contracted-the-virus-video.

JOE MURPHY, N. C.; JIACHUAN Wu; MUCCARI, R. (2021). Graphic: Coronavirus deaths in the u.s., per day. Retrieved from https://www.nbcnews.com/health/healthnews/coronavirus-deaths-united-states-each-day-2020-n1177936.

JONES M., P. (2019, April 16). Alberto Fernandez and the Pandemic: From co-president of half of Argentines to President of all. Csis. Retrieved from 
https://www.csis.org/analysis/alberto-fernandez-and-pandemic-co-president-half-argentinespresident-all

KARAKIZA, M. (2015). The impact of social media in the public sector. Procedia-Social and Behavioral Sciences, 175 , 384-392.

KHAN, G. F., YOON, H. Y.; PARK, H. W. (2014). Social media communication strategies of government agencies: Twitter use in Korea and the USA. Asian Journal of Communication, 24 (1), 60-78.

KREIS, R. (2017). The "tweet politics" of President Trump. Journal of language and politics, $16(4), 607-618$.

KU`SEN, E.; STREMBECK, M. (2018). Politics, sentiments, and misinformation: An analysis of the twitter discussion on the 2016 Austrian Presidential elections. Online Social Networks and Media, 5 , 37-50.

LUTU, P. E. N. (2019). Using Twitter mentions and a graph database to analyse social network centrality. In 2019 6th International Conference on Soft Computing \& Machine Intelligence (iscmi) (pp. 155-159).

MATHUR, A.; KUBDE, P.; VAIDYA, S. (2020). Emotional analysis using Twitter data during pandemic situation: Covid-19. In 2020 5th International Conference on Communication and Electronics Systems (ICCES) (pp. 845-848).

MCCORMICK, R. (2016, November 13). Donald Trump says Facebook and Twitter 'helped him win'. CNN World. Retrieved from

https://www.theverge.com/2016/11/13/13619148/trump-facebook-twitter-helped-win.

MERGEL, I. (2013). Social media adoption and resulting tactics in the US Federal Government. Government Information Quarterly, 30 (2), 123-130.

MOSSBERGER, K.; WU, Y.; CRAWFORD, J. (2013). Connecting citizens and local governments? Social media and interactivity in major us cities. Government Information Quarterly, 30 (4), 351-358.

MUNDO, R. B. N. (2019, May 18). Paso | Quienes Alberto Fernandez, el candidato a la presidencia de Argentina que comparte la formula con Cristina Kirchner. BBC News Mundo. Retrieved from https://www.bbc.com/mundo/noticias-america-latina-48323822.

NAI, A. (2020). The Trump paradox: how cues from a disliked source foster resistance to persuasion. Politics and Governance, 8 (1), 122-132.

NARAYANRAO, P. V.; KUMARI, P. L. S. (2020). Analysis of machine learning algorithms for predicting depression. In 2020 international conference on computer science, engineering and applications (iccsea) (pp. 1-4).

NEWTON, P. (2020, December 15). Canada begins Vovid-19 vaccinations, but officials fear supply issues due to global scramble. CNN World. Retrieved from https://edition.cnn.com/2020/12/14/americas/ canada-covid-19-vaccinations/index.html. 
PURNOMO, A.; AGUSTINA, I. A.; SEPTIANTO, A.; PRASETYO, Y. E., et al. (2020). Instagram literature: Insights from scientometric application. In 2020 international confer ence on information management and technology (icimtech) (pp. 583-587).

RECUERO, R.; SOARES, F. B.; GRUZD, A. (2020). Hyperpartisanship, disinformation and political conversations on twitter: The Brazilian presidential election of 2018. In Proceedings of the International AAAI Conference on Web and Social Media (Vol. 14, pp. 569-578).

RECUERO, R.; ZAGO, G.; SOARES, F. (2019). Using social network analysis and social capital to identify user roles on polarized political conversations on Twitter. Social Media+ Society , 5 (2), 2056305119848745.

RIEGER, J.(2020, November 2).The Washington post (2020). 40 times Trump said the Coronavirus would go away. The Washington post. Retrieved from https://www.washingtonpost.com/video/politics/40-times-trump-said-the-coronavirus-wouldgo-away/2020/04/30/ d2593312-9593-4ec2-aff7-72c1438fca0e video.html

RYABCHENKO, N.; MALYSHEVA, O. (2017). How to become a President: Election technologies in the post-truth and fake news era. Man in India, 97 (23), 507- 527.

SLIMOVICH, A. (2016). Politica y redes sociales en argentina. el caso de los candidatos presidenciales de 2011 en Twitter. Signo y Pensamiento, 35 (68), 86-100.

THIJS, B.; GL“ANZEL, W. (2018). The contribution of the lexical component in hybrid clustering, the case of four decades of "scientometrics". Scientometrics, 115 (1), 21-33.

TWINT PROJECT. (2017). Twint - Twitter intelligence tool. Retrieved from http://web.archive.org/web/20080207010024/http://www.808multimedia.com/winnt/kernel.ht $\mathrm{m}$.

TWITTER. (2020). Permanent suspension of @realdonaldtrump. Retrieved from https://blog.twitter.com/en us/topics/company/2020/suspension.html.

TWITTER. (2020, October 29). Shareholder letter. Retrieved from https://investor.twitterinc.com/home/default.aspx.

VOSVIEWER. (2020). ”vosviewer". Retrieved from https://www.vosviewer.com/

WAISBORD, S.; AMADO, A. (2017). Populist communication by digital means: presidential Twitter in latin america. Information, communication \& society , 20 (9), 1330-1346.

YUM, S. (2020). Social network analysis for Coronavirus (covid-19) in the United States. Social Science Quarterly, 101 (4), 1642-1647.

Main supplementary file: https:/www.dropbox.com/sh/w43tv8jdhji2nqe/AADjrK8359kIkpHyQVT081Jga?dl=0 